\title{
Diversity and Abundance of Outdoor Mosquitoes and Their Relationship to Rainfall Index in Binong Village, Tangerang District
}

\author{
Dewi M Yuliani ${ }^{1}$, Upik Kesumawati Hadi ${ }^{2 *}$, Susi Soviana ${ }^{2}$, E B Retnani ${ }^{3}$ \\ ${ }^{1}$ Post Graduate Student of Doctoral Program, Program Study of Parasitology and Medical Entomology, IPB University, \\ Dramaga, Bogor 16680, Indonesia \\ ${ }^{2}$ Entomology Laboratory, Division of Parasitology and Medical Entomology, Faculty of Veterinary Medicine, IPB \\ University, Dramaga, Bogor 16680, Indonesia \\ ${ }^{3}$ Helminthology Laboratory, Division of Parasitology and Medical Entomology, Faculty of Veterinary Medicine, IPB \\ University, Dramaga, Bogor 16680, Indonesia, \\ *Corresponding author. Email: upikke@ipb.ac.id
}

\begin{abstract}
Mosquitoes are distributed worldwide in tropical and temperate regions. The abundance of mosquitoes, provides a significant level of risk in transmitting pathogens and nuisance to humans. The aims of this study were (1) to measure the abundance and dominance of outdoor mosquitoes during daytime and (2) analyse the correlation of mosquito density and rainfall index. This research was conducted in Binong village for six months, since January to June 2018. Human Landing Collection (HLC) method was used from 6:00 AM to 06:00 PM outside the house, by five collectors, once in every two weeks. The results of the study showed there were four species of outdoor mosquitoes during the day such as Aedes albopictus which has the highest abundance, followed by Armigeres subalbatus, Aedes aegypti and Culex quinquefasciatus. The highest abundance of Ae. albopictus occurred in May (80.53\%), Ar. subalbatus in January (21.28\%), Ae. aegypti in June (16.30\%) and Cx quinquefasciatus in March (2.65\%). The correlations between rainfall index and density of Ae. albopictus $(\mathrm{r}=0.195$ and $\mathrm{p}=0.712)$, Ar. subalbatus $(\mathrm{r}=0.025$ and $\mathrm{p}=0.963)$, and Ae. aegypti $(\mathrm{r}=0.181$ and $\mathrm{p}=0.731)$ were not significant. Only $C x$. quinquefasciatus showed a significant correlation with rainfall index $(\mathrm{r}=0.894$ and $\mathrm{p}=0.016)$. Cx. quinquefasciatus was found at several sites because of the existence of ditches which served as breeding place of $C x$. quinquefasciatus. The ditches were also easily stagnated when it rains. Meanwhile, the breeding place of Ae. albopictus and Ae. aegypti were hidden and the eggs were dry resistant.
\end{abstract}

Keywords: Aedes albopictus, rainfall index, density of mosquito, outdoors

\section{INTRODUCTION}

Mosquitoes are distributed worldwide in both tropical and temperate regions [1]. The abundance of mosquitoes in nature, provides a significant level of risk in the transmission of pathogens and nuisance to humans and increasing human morbidity and mortality to a disease epidemic [2]. Mosquitoes are vectors of several pathogens that cause disease in humans, namely malaria, dengue fever, Japanese encephalitis, and chikungunya [3].

Mosquitoes are small, smooth, slender insects, their legs are long and slim, and have mouth parts that can pierce skin and suck blood. Mosquitoes are widespread throughout the world, ranging from the polar regions to the tropics, and can be found at an altitude of 5000 meters above sea level to a depth of 1500 meters below ground level in mining areas [4].
Aedes sp. and Culex sp. are very invasive, quick to adapt to artificial environment, and found throughout the world due to human activities [5]. Mosquitoes have the ability to live in urban areas because of (1) availability of places for female mosquitoes to lay their eggs and breed, (2) availability of hosts to suck blood. Changes in the environment can affect mosquito populations. Mechanisms that can influence population dynamics are (1) exogenous, namely rainfall and temperature, and (2) endogenous, namely large mosquito populations [6]. Rainfall and temperature are climate variables that play major roles in the dynamics of urban mosquito populations. Artificial environments can expand the habitat of certain species of mosquitoes, increase their abundance and reduce the diversity of mosquito species which greatly influences the vector ecology and epidemiology of infectious diseases [7]. Ae albopictus, also known as Asian tiger mosquito, is an invasive mosquito that can be found in the tropics and 
temperate regions. The spread of mosquitoes in the last three decades is caused by human activities [8]. In the middle of 1980 to 2000, Ae. albopictus was a species that spreads very fast and invasive throughout the world [9]. The development of urban industries in Asia caused Ae. albopictus to replace the role of Ae. aegypti as a disease vector because it predominantly sucks blood during the day. These mosquitoes are more adaptable in urban environments [10].

Binong Village is one of the dengue endemic villages in Tangerang District, and there was a Chikungunya Outbreak in August 2014. This research was conducted to (1) measure the abundance and dominance of outdoor mosquitoes during daytime and (2) analysed the relationship between mosquito density and rainfall index. The results of this study are expected to develop more effective control models in preventing the spread of vector-borne diseases.

\subsection{Materials and Methods}

This research was conducted in 1440 houses in Binong Village, Tangerang District, Indonesia (Figure 1). The study was done in two seasons, the rainy season (January to March 2018) and the dry season (April to June 2018). Adult mosquito collection was carried out every 2 weeks from 06.00 AM to 06.00 PM with Human Landing Collection (HLC) method outside the house. Mosquito collection were carried out by five persons, sitting with their pants rolled to their knees and waiting for 20 minutes for mosquitoes to arrive.

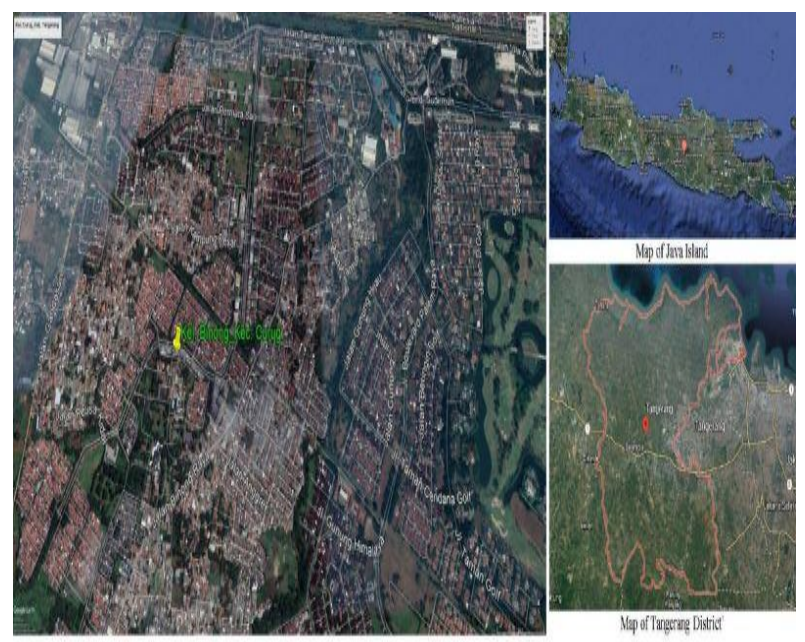

Figure 1 Map of Binong Village, Tangerang District
The mosquitoes that landed on human legs were immediately captured with an aspirator and placed into paper cups and then stored inside a cool box to be transported to the laboratory and identified using a mosquito identification key [11].

Weather data were obtained from the Meteorological, Climatological and Geophysical Agency in Tangerang. The monthly rainfall index value was calculated by multiplying the amount of rainfall per month by the rainy day per month, then divided by the number of days in the month. Data were analysed using Pearson's correlation.

\subsection{Our Contribution}

This paper presents the diversity of mosquitoes outside the house during the daytime in Binong Village, Tangerang. Tangerang District does not have diversity and abundance data of mosquito species, although most of the area could serve as the breeding places of mosquitoes. Diversity and abundance of mosquitoes outside the house during the daytime can provide information of vector borne disease possibility in Tangerang District. The correlation between mosquito density outside the house during daytime and rainfall index in Binong Village could be useful for the prevention and control programme of vector borne diseases in Binong Village, Tangerang.

\subsection{Paper Structure}

The rest of the paper is organized as follows. Section 2 introduces the diversity and dominance of mosquitoes outside the house during daytime in Binong village, Tangerang using HLC method every two weeks for six months. Section 3 presents the relationship between density of mosquitoes outside the house during daytime and rainfall index in Binong Village January until June 2018. Finally, section 4 concludes the paper and presents suggestion for future research.

\section{RESULTS AND DISCUSSION}

The results of mosquito collection outside the house during the daytime were presented in Table 1 and Figure 2. Four species of mosquitoes were collected in Binong Village, namely Ae. albopictus which has the highest abundance, followed by Ar. subalbatus, Ae. aegypti, and $C x$. quinquefasciatus. Figure 2 showed that the highest abundance of Ae. albopictus occurred in May (80.53\%), Ar. subalbatus in January (21.28\%), Ae. aegypti in June (16.30\%), and Cx quinquefasciatus in March (2.65\%). 
Table 1 Diversity and Abundance of Outdoor Mosquitoes during the Daytime using the HLC method in January-June 2018 in Binong Village, Tangerang District

\begin{tabular}{|c|c|c|c|c|c|c|c|c|}
\hline Species & Month & January & February & March & April & May & June & $\begin{array}{c}\text { Total } \\
\text { Average } \pm \text { Sd }\end{array}$ \\
\hline \multirow{3}{*}{ Ae. albopictus } & Abundance (\%) & 76.29 & 75.62 & 77.88 & 78.87 & 80.53 & 79.77 & $78.16 \pm 1.94$ \\
\hline & Frequency & 1.00 & 1.00 & 1.00 & 1.00 & 1.00 & 1.00 & $1.00 \pm 0.00$ \\
\hline & Dominance & 76.29 & 75.62 & 77.88 & 78.87 & 80.53 & 79.77 & $78.16 \pm 1.94$ \\
\hline \multirow{3}{*}{ Ar. subalbatus } & Abundance (\%) & 21.28 & 17.81 & 5.31 & 7.04 & 5.79 & 3.93 & $10.19 \pm 7.39$ \\
\hline & Frequency & 0.94 & 0.75 & 0.23 & 0.29 & 0.23 & 0.14 & $0.43 \pm 0.33$ \\
\hline & Dominance & 20.00 & 13.36 & 1.22 & 2.04 & 1.33 & 0.55 & $6.42 \pm 8.24$ \\
\hline \multirow{3}{*}{ Ae. aegypti } & Abundance (\%) & 2.43 & 5.62 & 14.16 & 12.21 & 13.16 & 16.30 & $10.65 \pm 5.40$ \\
\hline & Frequency & 0.17 & 0.31 & 0.54 & 0.48 & 0.48 & 0.54 & $0.42 \pm 0.15$ \\
\hline & Dominance & 0.41 & 1.74 & 7.65 & 5.86 & 6.32 & 8.80 & $5.13 \pm 3.33$ \\
\hline \multirow{3}{*}{$\begin{array}{c}\text { Cx. } \\
\text { quinquefasciatus }\end{array}$} & Abundance (\%) & 0.00 & 0.94 & 2.65 & 1.88 & 0.53 & 0.00 & $1.00 \pm 1.07$ \\
\hline & Frequency & 0.00 & 0.06 & 0.12 & 0.08 & 0.02 & 0.00 & $0.05 \pm 0.05$ \\
\hline & Dominance & 0.00 & 0.06 & 0.31 & 0.15 & 0.01 & 0.00 & $0.09 \pm 0.12$ \\
\hline \multirow{3}{*}{ Total Average \pm SD } & Abundance (\%) & $25.00 \pm 35.49$ & $25.00 \pm 34.49$ & $25.00 \pm 35.60$ & $25.00 \pm 36.16$ & $25.00 \pm 37.38$ & $25.00 \pm 37.17$ & \\
\hline & Frequency & $0.53 \pm 0.52$ & $0.53 \pm 0.42$ & $0.47 \pm 0.39$ & $0.46 \pm 0.39$ & $0.43 \pm 0.42$ & $0.42 \pm 0.45$ & \\
\hline & Dominance & $24.18 \pm 35.98$ & $22.70 \pm 35.78$ & $21.77 \pm 37.55$ & $21.73 \pm 38.17$ & $22.05 \pm 39.08$ & $22.28 \pm 38.54$ & \\
\hline
\end{tabular}




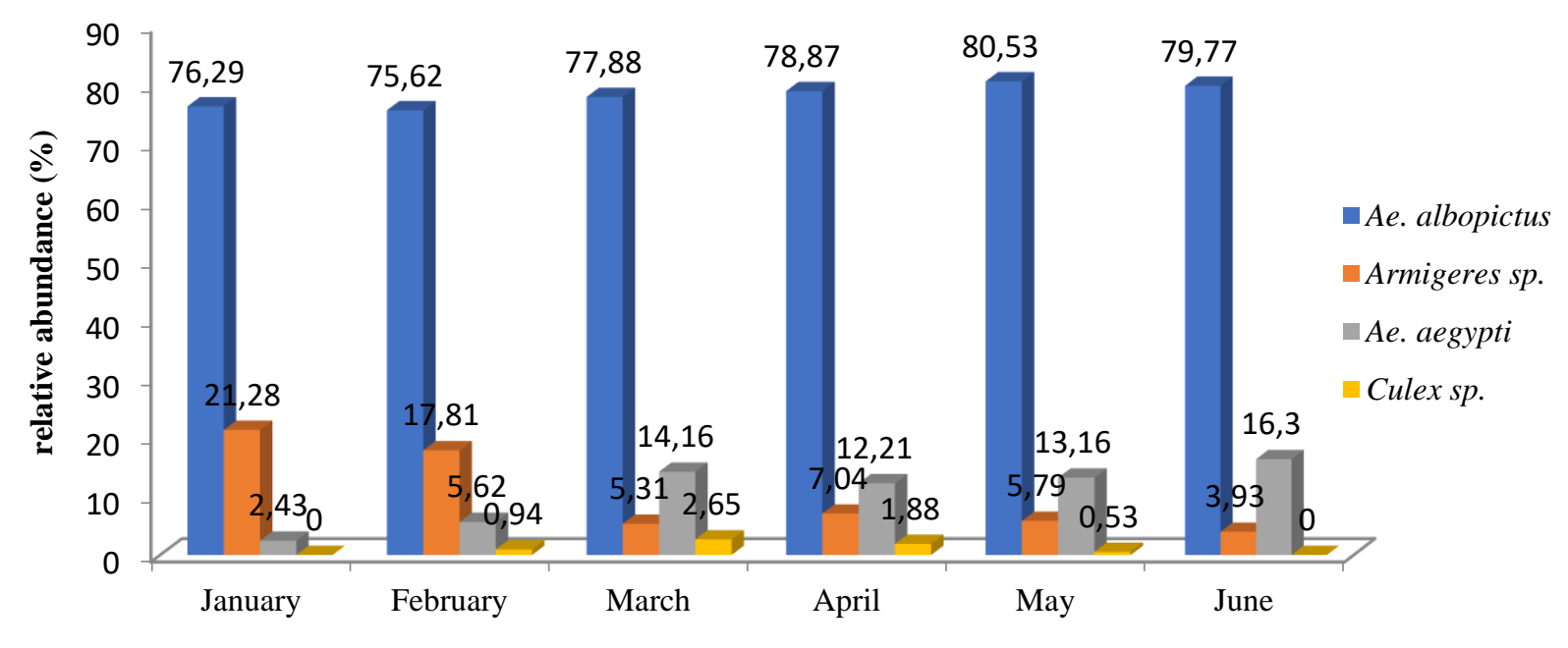

Month

Figure 2 The abundance of outdoor mosquitoes during daytime using the HLC method January-June 2018 in Binong Village, Tangerang District

Diversity of mosquitoes which had been collected during daytime in Binong Village for six months, includes Ae. albopictus which had the highest abundance, followed by Ar. subalbatus, Ae. aegypti, and Cx. quinquefasciatus. The mosquito with the highest abundance and dominance was Ae. albopictus in May, while the mosquito that has the lowest abundance was $C x$. quinquefasciatus in March. Observed behaviour of Ae. albopictus includes sucking blood outside the house (exophagic) and resting outside the house (exophilic). Delatte et al. [12] reported that Ae. albopictus was exophagic and exophilic in La Reunion (France).

The existence of plants outside the house can be used as a resting place of Ae. albopictus. Increasing number of $A e$. albopictus population might not be separated from the number of mosquito breeding places. Containers found outside the house such as flower pots, jars, drums, and other used items can collect rainwater for Ae. albopictus to breed, and the population of mosquitoes will increase in the area. Fontenille and Toto [13] had collected adult mosquitoes in the cities of Douala and Yaounde in South Cameroon and Ae. albopictus was the most commonly found species or $35 \%$ of the total number of mosquitoes, followed by $A e$. aegypti, An. gambiae, Cx. quinquefasciatus, Cx antennatus, $C x$. perfuscus, Mansonia uniformis, and Mn. africana. The collection carried out in Younde City obtained more Ae. albopictus than in the city of Douala, this was due to higher number of used tires outside the house that could serve as Ae. albopictus breeding places. Sawabe et al. [14] reported that in 2003-2006 in Japan, out of all mosquitoes found in thirty-seven sampling locations, which were urban and suburban residential areas, $25.5 \%$ of them was Culex pipiens and $16.9 \%$ was Ae. albopictus. Delatte et al. [12] reported mosquitoes at outdoor location in the urban area of Saint Pierre, La Reunion Island, France, showed $\mathrm{Ae}$. albopictus as the most numerous species. This mosquito had a high peak activity at $05.30 \mathrm{PM}$ in the summer and 04.00
PM in the winter. Wilke et al. [15] reported in the city parks of Brazil, Ae albopictus was a species with high abundance compared to $C x$. quinquefasciatus. Ae fluviatilis, Ae. scapularis, Cx. nigripalpus, and Ae. aegypti.

Siregar and Makmur [16] conducted a study in two cities, Medan Municipality which had a high DHF incidence rate and Lahat Municipality which had a low DHF incidence rate. Ae aegypti was more commonly found in Medan Municipality, whereas Ae. albopictus was more commonly found in Lahat Municipality, because there was still many vegetation. Riwu [17] reported that in Bogor Municipality, three genera of mosquitoes were found inside and outside the house, namely Aedes, Culex, and Armigeres. The most dominant mosquito found was $C x$. quinquefasciatus (49.43\%), followed by Ae. aegypti, Ae. albopictus, Ar. subalbatus, and Cx. tritaeniorhyncus.

Aedes albopictus displayed opportunistic and zoophilic behaviours. Generally it serves as a weak vector for pathogens in humans such as arbovirus. The density of mosquito population is an important element that contributes to the occurrence of epidemics with limited vector competence. Ae albopictus showed a flexible ecology such as the places where larvae develop, bloodsucking behaviour, and adaptation to weather changes that could increase the potential for its spread in new environments which affects its presence among other vectors [18].

The results of correlation analysis between rainfall index and density of Ae. albopictus, Ar. subalbatus, Ae. aegypti, and $C x$. quinquefasciatus are presented in Figure 3. Density of Ae. albopictus ( $\mathrm{r}=0.195$ and $\mathrm{p}=0.712), A r$. subalbatus $(\mathrm{r}=0.025$ and $\mathrm{p}=0.963)$, and Ae. aegypti $(\mathrm{r}=$ 0.181 and $\mathrm{p}=0.731$ ) showed no significant correlation with rainfall index. Only $C x$. quinquefasciatus showed a significant correlation with rainfall index $(r=0.894$ and $p=$ 0.016). 
Ae. albopictus

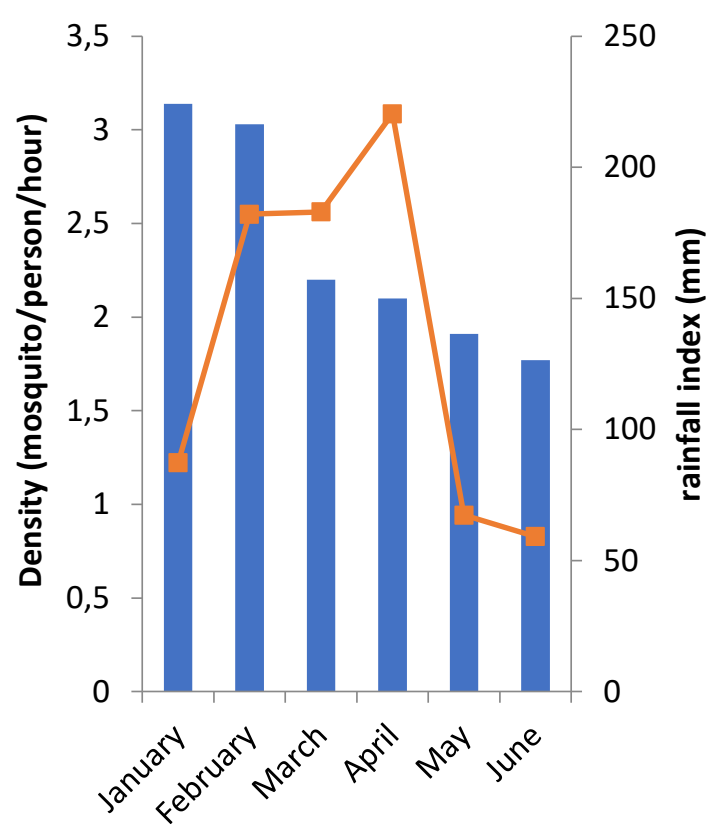

Ae. aegypti

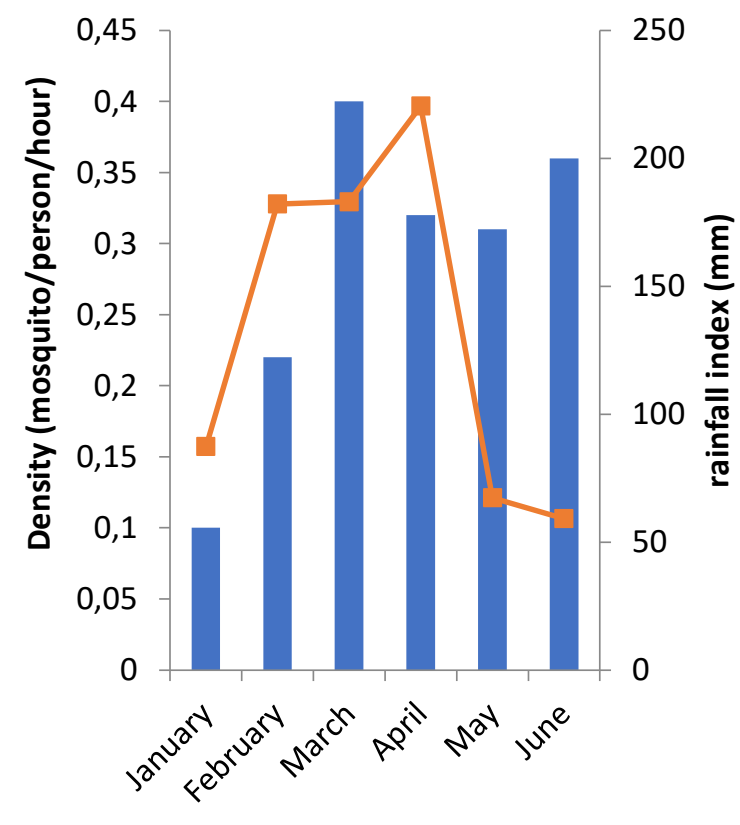

Ar. subalbatus

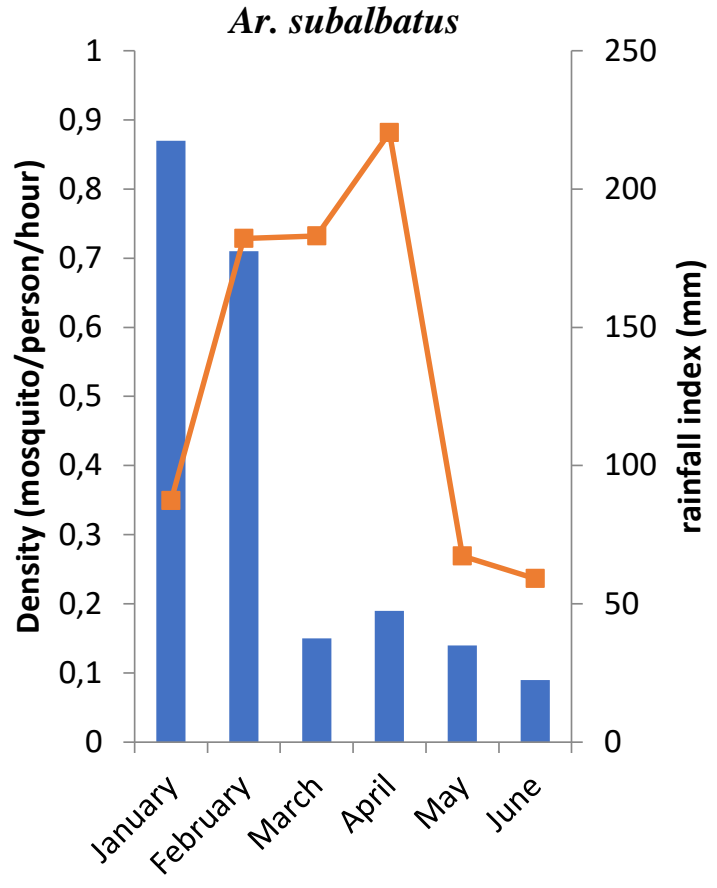

Cx. quinquefasciatus

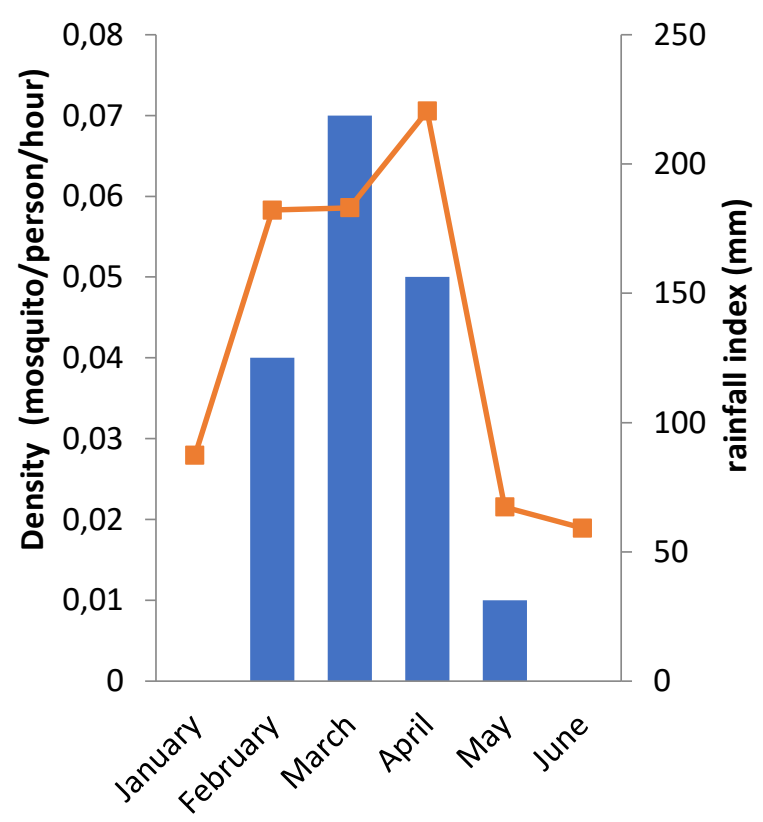

Figure 3 Relationship between mosquito density and rainfall index in January-June 2018 in Binong Village, Tangerang District 
mosquitoes of Government Reservation Area (GRA) of Enugu metropolis in Southeastern Nigeria, Proceedings of the 3rd Society for Occupational Safety and Environmental health (SOSEH), Annual National Conference, 2006, pp. $140-143$

[2] N. Moses, H. Saidu, J. Philimon, S. Mohammed, K. Abubakar, Study of man biting rate of mosquito (Diptera: Culicidae): A case study of Gombe State University of Nigeria, ARASET 3 (2016) 10-20

[3] D.J. Gubler, G. Kuno, Dengue and Dengue Haemorrhagic Fever, New York: CAB Publ, 1997

[4] U.K. Hadi, F.X. Koesharto, Nyamuk, di dalam: S.H. Sigit, U.K. Hadi, editor. Hama Permukiman Indonesia, Bogor: UKPHP IPB, 2006

[5] WHO, Zika Situation report, 2016, (http://www.int/emergencies/zika-virus/situationreport/ 19-february-2016/en/(accessed 4.1.16)

[6] M. Begon, J.L. Harper, C.R. Townsend, Ecology: individuals, populations and communities, Blackwell Science, 2006, 738p

[7] E. Descloux, M. Mangeas, C.E. Menkes, M. Lengaigne, A. Leroy, T. Tehei, L. Guillaumot, M. Teurlai, A.C. Gourinat, J. Benzler, A. Pfannstiel, J.P. Grangeon, N. Degallier, X. De Lamballerie, Climate based models for understanding and forecasting dengue epidemics, PLoS. Negl. .Trop. Dis. $\quad 6 \quad$ (2012) DOI:https://doi.org/10.1371/journal.pntd.0001470

Aedes albopictus was the most common mosquito found outside the house during daytime in Binong Village, Tangerang District, followed by Ar. subalbatus, Ae. aegypti and $C x$ quinquefasciatus. The density of $C x$. quinquefasciatus had significant correlation with rainfall index compared to three other types of mosquitoes.

\section{ACKNOWLEDGMENT}

This work was supported by Entomology Laboratory, Division of Parasitology and Medical Entomology, Faculty of Veterinary Medicine, IPB University and Tangerang District Health Office, especially the Binong Public Health Center.

\section{REFERENCES}

[1] A.E. Onyido, V.I Ezike, E.A. Nwankwo, N.A. Ozumba, Public health implication of giant trees in the proximity of human dwellings: Treehole

8] C. Paupy. H. Delatte, L. Bagny, V. Corbel, D. Fontenille D, Aedes albopictus, an arbovirus vector: From the darkness to the light, Microb. Infect. $\quad 11 \quad$ (2009) 1177-1185. DOI:https://doi.org/10.1016/j.micinf.2009. 05.005)

[9] N.G. Gratz, Critical review of the vector status of Aedes albopictus, Med. Vet. Entomol. 18(3) (2004) 215-227

[10] L. Lambrechts, T.W. Scott TW, D.J. Gubler, Consequences of the Expanding Global Distribution of Aedes albopictus for Dengue Virus Transmission, PloS. Negl. Trop. Dis. 4(5) (2020) e646, DOI:https://doi.org/10.1371/journal.pntd. 0000646)

[11] C.T. O’Connor, A. Soepanto, Identifikasi nyamuk Aedes dewasa, Ditjen P2MPL: Depkes RI, 2000 
[12] H. Delatte, A. Desvars, A. Bouetard, S. Bord, G. Gimonneau, G. Vourc'h, D. Fontenille, Blood feeding behaviour of Aedes albopictus, vector of chikungunya on La Reunion, Vector Borne Zoonotic Dis. 8 (2008) 25-34

[13] D. Fontenille, J.C. Toto, Aedes (Stegomyia) albopictus (Skuse), a Potential New Dengue Vector in Southern Cameroon, Emerg. Infect. Dis. 7 (2001)1066-1067

[14] K. Sawabe, H. Isawa, K. Hoshino, T. Sasaki, S. Roychoudhury, Y. Hiqa, S. Kasai, Y. Tsuda, I. Nishiumi, N. Hisai, S. Hamao, M. Kobayashi, Host-feeding habits of Culex pipiens and Aedes albopictus (Diptera: Culicidae) collected at the urban and suburban residential areas of Japan, J. Med. Entomol. 47(3) (2010) 442-450

[15] Wilke, A.B. Bruno, A. Medeiros-Sousa Ralph, W.M. Ceretti-Junior, M. Toledo, Mosquito populations dynamics associated with climate variations, Acta 2016, DOI:https://doi:10.1016/j.actatropica.2016.10.02 5

[16] F.A. Siregar, T. Makmur, Survey on Aedes mosquito density and pattern distribution of Aedes aegypti and Aedes albopictus in high and low incidence districts in north Sumatra province, IOP Conf. Series: Earth and Environmental Science. 2018

[17] Y.R. Riwu, Bioekologi nyamuk Aedes spp. dan deteksi keberadaan virus Chikungunya di kelurahan Pasir Kuda Kecamatan Bogor Barat [tesis], Bogor: Institut Pertanian Bogor. 2011

[18] M. Bonizzoni, G. Gasperi, X. Chen, A.A. James, The invasive mosquito species Aedes albopictus: current knowledge and future perspectives, Trends Parasitol. 29(9) (2013) 460-468, DOI:https://doi.org/10.1016/ j.pt.2013.07.003

[19] L.D. Valdez, G.J. Sibona, C.A. Condat, Impact of rainfall on Aedes aegypti populations, Ecol. Model. 385 (2018) 96-105

[20] K.C. Poh, L.F. Chaves, M.R. Nava, C.M. Roberts, C. Fredregill, R. Bueno, M. Debboun, G.L. Hamer, The influence of weather and weather variability on mosquito abundance and infection with West Nile virus in Harris County, Texas, USA, Sci. Total Environ. 675 (2019) 260-272 